\title{
Investigation on Organochlorine Pesticides Residues and Trace Metals in Melon (Colocynthis citrollus L.): A Survey
}

\author{
G. O. Olutona*, 0. O. Daniel \\ Department of Chemistry and Industrial Chemistry, College of Agriculture, Engineering and Sciences, Bowen University, Iwo, Nigeria
}

\section{$P A P E R \quad I N F O$}

\section{Paper history:}

Received 10 October 2019

Accepted in revised form 29 November 2019

\section{Keywords:}

Anthropogenic

Contamination

Food Security

Toxicology

\begin{abstract}
A $B$ S $S$ T R A A C
Several nations of the world are facing crisis level of acute food security and malnutrition which required urgent attention. Melon very rich in protein, oil, minerals, vitamins and good source of energy. As a result, the high contamination of melon with heavy metals and pesticide residues threatens human and ecosystem. Organochlorine Pesticides (OCPs) and trace metals were undertaken in melon obtained from five major towns in Nigeria. Analytical instruments were used to analyze the extracted OCPs from dichloromethane and digested melon samples, respectively. The overall metal content per site of the studied elements in the selected sites was determined and it was in the following decreasing order: Mokwa $>$ Bida $>$ Suleja $>$ Borgu $>$ Saki. The mean metal concentrations were in the following decreasing order: $\mathrm{Pb}>\mathrm{Zn}>\mathrm{Ni}>\mathrm{Co}>\mathrm{Cd}$. With exceptions of locations where $\mathrm{Ni}$ and $\mathrm{Pb}$ were below detection limit, the concentrations of $\mathrm{Pb}, \mathrm{Cd}$ and $\mathrm{Ni}$ in other locations were above WHO/FAO recommended limit. Concentrations of $\mathrm{Zn}$ and Co were below WHO/FAO limits. Out of 17 isomers of OCPs analyzed only five isomers were detected. The overall OCPs content per site of the studied elements in the selected sites was determined and it was in the decreasing order: Bida $>$ Borgu $>$ Saki $>$ Suleja. OCP was not detected in melon samples obtained from Mokwa. With exception of endosulfan II, endrin aldehyde, heptachlor, DDE and $\lambda$-BHC were above their respective maximum residual limit. Environmental monitoring and education are highly recommended.
\end{abstract}

doi: $10.5829 /$ ijee.2020.11.01.05

\section{INTRODUCTION}

Many countries of the world are facing crisis level of acute food security and malnutrition which required serious attention. Statistically, in 2017, 124 million people in 51 countries and in 2016, 108 million in 48 countries across the globe faced crisis levels of acute food security. Eleven of these countries are from Africa accounting for 37 million in which the largest number were in North-Eastern Nigeria, Republic of Congo, Somalia and Southern Sudan [1]. According to GRFS [1], malnutrition is defined as anomalous physiological disorder caused by deficiencies, excesses or imbalance in energy and or nutrients for an active, health life. This include under nutrition, micronutrients deficiencies, overweight and obesity. Malnutrition of all forms may be attributed to inadequate nutrient intake, repeated infectious diseases and or poor care and feeding practices.

Melon (Colocynthis citrillus L.), a herbaceous annual vegetable belonging to the family Cucurbitaceae is an important globally. Melon is usually planted during the rainy season and maturity stage is usually three to four months. The crop is usually inter-planted with some other tuber crops such as yam, cassava [2, 3] act as a source of weed [4] and runoff as well as soil enrichment. In Nigeria, the seed are usually consumed as a thickening for soup and sauce; sometimes fried and eaten as snack [5]. A valuable oil may be extracted from the seed which can be used in cooking and fry cake.

The oil and the seed are very rich in protein, oil, minerals, vitamins and good source of energy [2, 3]. Olaniyi [6] reported that the seed contain carbohydrate $(4.6 \mathrm{~g})$, protein $(0.6 \mathrm{~g})$, crude fibre $(0.6 \mathrm{~g})$, vitamin $\mathrm{C}(33 \mathrm{mg})$, calcium, $\mathrm{Ca}$ (17 g), phosphorus, $\mathrm{P}(16 \mathrm{mg})$, and potassium, K (230 mg) per $100 \mathrm{~g}$ edible seed. According to Albishri et al. [7] the seed oil contains $31.0-69.0 \%$ linoleic acid, $12.1-31.0 \%$ oleic, 7.8 $39.36 \%$ palmitic and $4.9-10.45 \%$ stearic acid. It was stated by Ivanova [8] that melon contain glucose, fructose and sucrose (4.6 to 16.0 or $18.0 \%$ ), starch $(4.5 \%)$, pectin, vitamin A, C, D, K from group B and E, carotene, folic, K, magnesium $(\mathrm{Mg}), \mathrm{P}$, sodium $(\mathrm{Na})$, selenium $(\mathrm{Se})$ and $\mathrm{Ca}$ and many aromatic compounds. 
According to Jeffrey [9] melon has admirable taste and medicinal value. Chen et al. [10] and Gill et al. [11] reported that it is recommended in treatment of liver, kidney and cardiovascular diseases, other ailment are: gout, rheumatism and patient with atherosclerosis in situation of anemia. Melon has good phyto-chemical properties such as antiinflammatory, analgesic and anti-oxidant properties [10, 11]. Azhari et al. [12] stated that melon seed oil is very rich in sterols, phospholipids and tacopherols.

Despite the fact that metals occur naturally in the soil, it is the anthropogenic activities that increase their amount in the soil and other environmental factors which portends human and ecosystem health. Anthropogenic activities such as mining, sewage sludge, waste water disposal, urban effluent, vehicle exhausts and agrochemicals can greatly affect heavy metal concentrations in soil [13]. Heavy metals in soil tend to interrupt soil function, bioaccumulate in plant and translocate into various organs of the crop.

Soil contamination by heavy metals may pose risks and health hazards to humans and the ecosystem in various ways such as direct assimilation, exchange with contaminated soil, consumption of contaminated water, the food cha, drop in food quality through phytotoxicity, decline in land usability for agricultural practices thereby given rise to food uncertainty, and land tenure problem [14].

Many prominent pesticides used extensively in agriculture possess substantial levels of metals, for instance, Bordeaux a mixture of copper sulphate and copper oxychloride chemicals is capable of aggregate the levels of copper in the soil [15]. Furthermore, application of animal manure, compost and household sewage may also contribute to the contamination of soil with heavy metals [16]. Copper and zinc growth promotant additives in poultry feed and arsenic in poultry health product are potential heavy metal contaminant in soil $[17,18]$.

Chlorinated organic pesticides reevaluated to be highly noxious, harmful and persistent in the environment [19]. It can accumulate in human as well as in animal bodies because it has ability to solubilize in fats and causes health problems such as cancer and hematopoietic, nephrotoxic, hepatotoxic, and reproductive diseases. Moreover, they also affect hormonal system, and may have interactive effects by producing both androgenic and estrogenic responses in vertebrates. In invertebrates this pesticides may cause endocrine disruption, neurological and immunodeficiency disorders [20]. DDT like other OCs is not acutely toxic which the major reason of its widespread use. It persists for a long time in environment, and accumulates in food and animal tissues. The inadequate use of DDT resulted in worldwide pollution which makes it a threat for whole web of life. The residues of DDT mainly its metabolite DDE was observed in all fish eating birds, in fishes it is the major cause of reproductive failure [21]. DDT persists for very long time and stored in various tissues with highest accumulation in fat where repeated exposure accumulates high concentration. This property of storage in all tissues causes serious health issues mostly in occupational exposure to DDT. Various reports have confirmed its carcinogenic effects as it is the major cause of pancreatic cancer, liver cancer and multiple myeloma [22]. Endosulfan is one of the OCs that has found to use very extensively. The enormous use of endosulfan makes it vulnerable for the whole environment. The extensive use of endosulfan deteriorate soil quality, its biology, fertility, health and productivity [23]. The most alarming chronic symptoms, like testicular and prostate cancer, breast cancer, sexual abnormality, endocrine disruption and stomach contact poison, has also been reported by endosulfan. Lindane is used as an insecticide on fruits and vegetables. It is an organochlorinated insecticide has severe health effects. In humans it also causes induce membrane perturbation, functional impairment in blood brain barrier, disturbance in glutathione homeostasis and alteration in monooxygenase enzymes [24] which ultimately causes neurotoxicity.

The occurrence of pesticides in our environment as a result of the indiscriminate or intentional use has resulted in its persistence in the environment, thereby affecting the ecosystems and non- target organisms. Acute and chronic pesticide poisoning usually results from consumption of contaminated food, chemical accident in industries and occupational exposure in agriculture. Hence, this study aimed to assess the levels of trace metals and organochlorine pesticides residue in melon seeds.

\section{MATERIALS AND METHODS \\ Sampling}

The study was performed in five different towns namely, Borgu, Suleja, Mokwa, Bida and Saki from five different Local Government in Nigeria, four of which from northern state and one from south-west Nigeria. Two kilograms of melon were purchased from each town.

\section{Trace metals analysis}

The melon seed $(1.0 \mathrm{~g})$ were digested for trace metals analysis by adding $5 \mathrm{~mL}$ of nitric followed by adding $1 \mathrm{~mL}$ of perchloric acid after heating for about $10 \mathrm{~min}$. The heating was continued gently until frothing subsided. The sample was heated until near dryness, allowed to cool and filtered into 25 $\mathrm{ml}$ standard flask. The filtrate was then made up to the mark with distilled water.

From stock solution, the calibration curves for heavy metals were plotted at several levels $(0.25,0.5,0.75,1.0,2.0$, 0.35 , and $5.0 \mathrm{mg} / \mathrm{L}$ ). Stock solution was prepared from standard reference materials $(1000 \mathrm{ppm})$. The linearity of the calibration plots attained were: Co (0.99956), Zn (0.99940), $\mathrm{Pb}$ (0.99798), Cd (0.99987), and Ni (0.99617), respectively. The limit of detection (LOD) and Limit of quantification (LOQ) for the trace metals were $\mathrm{Ni}$ (0.008: 0.08); $\mathrm{Cd}(0.0028$ : 0.028), $\mathrm{Pb}$ (0.012:0.12), Zn (0.003:0.03), and Co (0.02:0.2).

\section{Extraction, cleanup and gas chromatography analysis}

Soxhlet extractor was employed in extracting $20 \mathrm{~g}$ each of the sample using dichloromethane as solvent. Extraction was performed for $4 \mathrm{~h}$ until clear solvent was observed. The cleanup of the samples was performed by silica gel (60-120 mesh) chromatography and the final elution was achieved by using dichloromethane. The eluate was concentrated under vacuum to about $1 \mathrm{~mL}$ and store in a well labelled vials prior GC analysis.

Qualitative and quantitative analysis of organochlorine was carried out by Agilent 7890A gas chromatography with a splitless injector port equipped with electron capture detector 
and a DB $1730 \mathrm{~m}$ (length) $\times 250 \mathrm{um} \times 0.25$ um film thickness column. The injector temperature was $250^{\circ} \mathrm{C}$. There was split flow rate of $2 \mathrm{~mL} / \mathrm{min}$ during an oven temperature of $150^{\circ} \mathrm{C}$ which was increased to $280^{\circ} \mathrm{C}$ at $6^{\circ} \mathrm{C} / \mathrm{min}$, the total run time was $21.67 \mathrm{~min}$.

The chromatograms of the chlorinated organic compounds mix standards $(2 \mathrm{ng} / \mu \mathrm{L})$ and representative chromatograms of chlorinated organic compounds of melon sample analyzed are shown in Figure 1. The peak areas of the several peaks whose retention times correspond with the standards were inferred on their equivalent calibration curves to attain the

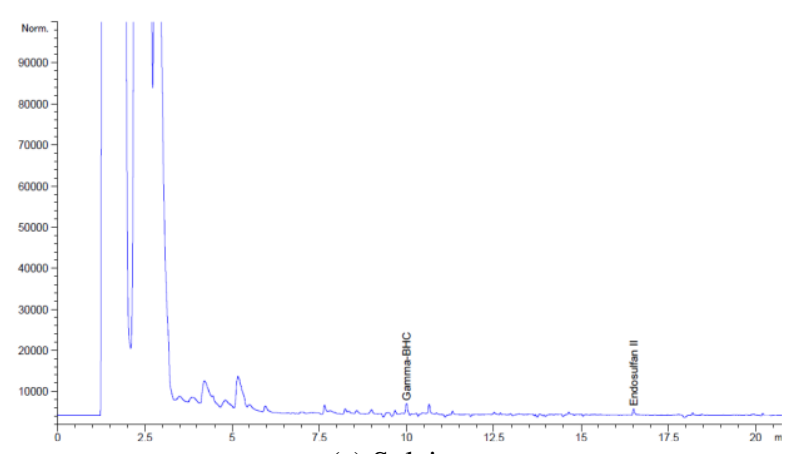

(a) Suleja

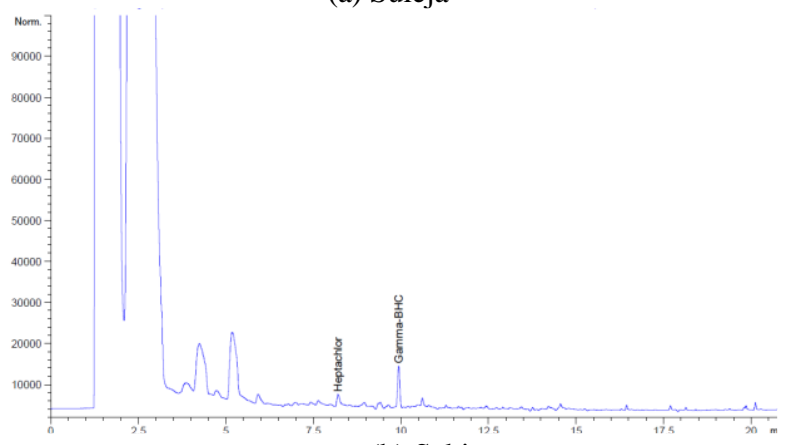

(b) Saki

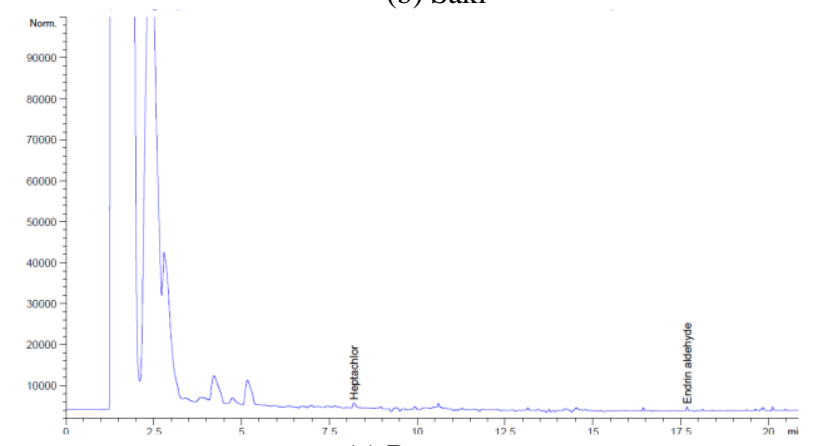

(c) Borgu

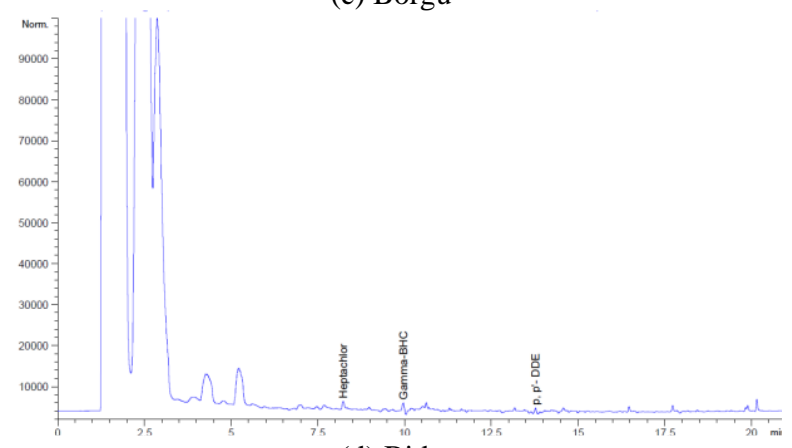

(d) Bida

Figure 1. (a-d) Chromatograms of OCPs residues in melon seed of the sites considered in this study concentration. The retention times for heptachlor, $\lambda$-BHC, p,p' - DDE, endosulfan II and endrin aldehyde are:8.229,9.958, 13.770, 16.503 and 17.681 minutes, respectively. The limits of detection and quantifications $(\mathrm{ng} / \mu \mathrm{L})$ were: heptachlor $((0.094 ; 0.94), \alpha \mathrm{BHC}(0.065 ; 0.65)$, $\beta$ BHC $\quad(0.094 ; 0.94) ; \quad \lambda$-BHC $\quad(0.057 ; 0.57), \quad \delta B H C$ $(0.017 ; 0.17)$, p. p' -DDT $(0.078 ; 0.78)$, p. p' -DDE $(0.040$; $0.40)$, p. p' - DDD $(0.082 ; 0.82)$, aldrin $(0.031 ; 0.31)$, heptachlor epoxide $(0.023 ; 0.23)$, dieldrin $(0.071 ; 0.71)$, endrin $(0.112 ; 1.12)$ endosulfan II $(0.141 ; 1.41)$, and endrin aldehyde $(0.057 ; 0.57)$, endosulfan sulphate $(0.122 ; 1.12)$ and methoxychlor $(0.405 ; 4.05)$, respectively.

\section{RESULTS AND DISCUSSION \\ Heavy metals}

Five metals cadmium, $\mathrm{Zn}, \mathrm{Co}, \mathrm{Pb}$, and $\mathrm{Ni}$ were analyzed from melon seeds obtained from the five towns in five different local governments of Nigeria and the obtained results are presented in Table 1.

The total metal burden per site of the studied elements in the selected sites was determined and it was in the following decreasing order: Mokwa > Bida > Suleja > Borgu > Saki. The overall metal concentrations were in the following decreasing order: $\mathrm{Pb}>\mathrm{Zn}>\mathrm{Ni}>\mathrm{Co}>\mathrm{Cd}$. Cadmium is not known for any essential biological function. The concentrations of Cd were found to be in the range of $0.1 \mathrm{mg} /$ $\mathrm{kg}$ to $1.35 \mathrm{mg} / \mathrm{kg}$ which were well above the WHO/FAO limits of 0.05 . This is very dangerous as cadmium poisoning can lead to painful bone disease combined with kidney malfunction [25].

Zinc is an essential trace element for both animals and humans. A deficiency of $\mathrm{Zn}$ is marked by retarded growth, loss of taste, and decreased fertility. High concentrations of $\mathrm{Zn}$ can cause irritability, muscular stiffness and pain, loss of appetite, and nausea [26]. Borgu local government had the highest concentration of zinc at $(16.85 \mathrm{mg} / \mathrm{kg})$ and Mokwa local government area had the lowest at $(5.23 \mathrm{mg} / \mathrm{kg})$ which is lower than the WHO/FAO limit of $50 \mathrm{mg} / \mathrm{kg}$.

Lead accumulates in the body organs (i.e., brain), which may lead to poisoning or even death. The gastrointestinal tract, kidneys, and central nervous system are also affected by the presence of lead. Children exposed to lead are at risk for impaired development, lower IQ, shortened attention span, hyperactivity, and mental deterioration, with children under the age of six being at a more substantial risk. Adults usually experience decreased reaction time, loss of memory, nausea, insomnia, anorexia, and weakness of the joints when exposed to lead [27]. Lead performs no known essential function in the human body, it can merely do harm after uptake from food, air, or water. Only three of the five local government contained $\mathrm{Pb}$ and their concentrations were at very alarming rates. Mokwa had the highest concentration at $(19.75 \mathrm{mg} / \mathrm{kg})$, Bida at $(13.70 \mathrm{mg} / \mathrm{kg})$ and Suleja at $(11.43 \mathrm{mg} / \mathrm{kg})$ which are all way above the $\mathrm{WHO} / \mathrm{FAO}$ limits at 0.05 respectively. The gastrointestinal tract, kidneys, and central nervous system can be affected by high concentrations of $\mathrm{Pb}$.

Nickel is an element that occurs in the environment only at very low levels and is essential in small doses, but it can be dangerous when the maximum tolerable amounts are exceeded. This can cause various kinds of cancer on different 
TABLE 1. Concentration of Trace Metals $(\mathrm{mg} / \mathrm{kg}$ ) in melon seeds

\begin{tabular}{lcccccc}
\hline Location & Cd & Zn & Co & Pb & Ni & Total Metal Burden \\
\hline Bida & $0.10 \pm 0.000$ & $8.33 \pm 0.050$ & $<0.02$ & $13.7 \pm 0.050$ & $1.78 \pm 0.025$ & 23.9 \\
Borgu & $0.53 \pm 0.050$ & $16.9 \pm 0.050$ & $0.475 \pm 0.025$ & $<0.012$ & $1.63 \pm 0.050$ & 19.5 \\
Mokwa & $1.35 \pm 0.500$ & $5.3 \pm 0.050$ & $2.300 \pm 0.050$ & $19.8 \pm 0.250$ & $3.56 \pm 0.050$ & 32.2 \\
Saki & $1.00 \pm 0.000$ & $9.23 \pm 0.025$ & $<0.02$ & $<0.012$ & $<0.008$ & 10.2 \\
Suleja & $0.43 \pm 0.025$ & $6.18 \pm 0.025$ & $2.58 \pm 0.025$ & $11.4 \pm 0.050$ & $<0.008$ & 20.6 \\
\hline WHO/FAO & 0.05 & 50 & 50 & 0.05 & 0.5 & \\
\hline
\end{tabular}

sites within the bodies of animals. Mokwa had the highest concentration at $(3.55 \mathrm{mg} / \mathrm{kg})$ followed by Bida at $(1.78 \mathrm{mg} /$ $\mathrm{kg}$ ) while that of Borgu was $(1.63 \mathrm{mg} / \mathrm{kg})$. All these concentrations exceeded the WHO/FAO limits of $0.5 \mathrm{mg} / \mathrm{kg}$.

Cobalt is essential in trace amounts for humans and other mammals as it is an integral component of the vitamin B12 complex but in higher it causes respiratory irritation, wheezing, asthma, decreased lung function, pneumonia, and fibrosis. Co was not in detected in Bida and Suleja. Suleja had a concentration of $2.58 \mathrm{mg} / \mathrm{kg}$ while Borgu and Mokwa had $0.48 \mathrm{mg} / \mathrm{kg}$ and $2.30 \mathrm{mg} / \mathrm{kg}$ respectively. Cobalt in the in these samples were all within the WHO/FAO limit of 50 $\mathrm{mg} / \mathrm{kg}$.

Oluwabamiwo [28] carried out research on heavy metals analysis of melons seeds from Lagos state, Nigeria. The research revealed the concentrations of $\mathrm{Pb}, \mathrm{Cd}, \mathrm{Zn}$ to be 0.05 $\mathrm{mg} / \mathrm{kg}, 0.005 \mathrm{mg} / \mathrm{kg}$ and $8.18 \mathrm{mg} / \mathrm{kg}$, respectively. Lead concentration was below the WHOFAO limit, Cd was also lower than the WHO/FAO limit, and $\mathrm{Zn}$ was within the WHO/FAO limit.

Lanre-Iyanda and Adekunle [29] investigated the presence of some heavy metals in melon cakes (called Robo in Yoruba) sold at different motor parks in Abeokuta, Nigeria, the motor parks were Asero, Adata, Sapon, Ia-oshin, Lafenwa, Itoku, Kuto. The concentrations were $\mathrm{Zn}$ (ranged from 16.15 to $21.78 \mathrm{mg} / \mathrm{kg}$ ) all the concentrations of zinc were within the FAO/WHO limit, Cd (ranged from 0.028 to $0.057 \mathrm{mg} / \mathrm{kg}$ ) the concentrations of cadmium in Lafenwa motor park was slightly above the WHO/FAO limit, $\mathrm{Pb}$ (ranged from 13.83 to $19.88 \mathrm{mg} / \mathrm{kg}$ ) $\mathrm{Pb}$ in the melon cakes from the different motor parks were all above the WHO/FAO limit of 0.05 $\mathrm{mg} / \mathrm{kg}$, Ni (ranged from 0.04 to $0.15 \mathrm{mg} / \mathrm{kg}$ ) $\mathrm{Ni}$ in all the melon cakes from the different motors parks were below the limit. In comparison of the values reported by Lanre-Iyanda and Adekunle [29] to the values obtained in this study, the $\mathrm{Zn}$ concentrations in this study were lower. The $\mathrm{Cd}$ and $\mathrm{Ni}$ values in this study were higher, while the $\mathrm{Pb}$ values were in close ranged.

Ogunkunle et al. [30] carried out research on the analysis of heavy metals in some fruits and vegetables from Lagos. One of the fruits on which heavy metals analysis was carried out is watermelon, the concentrations of $\mathrm{Co}, \mathrm{Zn}, \mathrm{Pb}, \mathrm{Ni}, \mathrm{Cd}$ were found to be $0.02 \mathrm{mg} / \mathrm{kg}, 0.05 \mathrm{mg} / \mathrm{kg}, 1.76 \mathrm{mg} / \mathrm{kg}, 0.14$ $\mathrm{mg} / \mathrm{kg}$, and $0.004 \mathrm{mg} / \mathrm{kg}$, respectively. Only that of $\mathrm{Pb}$ was higher than the WHO/FAO permissible limit.

Savsatli et al. [31] reported on presence of some heavy metals in bitter melon seeds grown in Pazar district of Rize Province in Black Sea Region of Turkey. The concentrations (mg/0.1 kg) were Cd (0.002), Pb (0.02), Zn (0.04), Ni (0.03) these values are lower than the values obtained in this study. Verma [32] also carried out a similar research in bitter melon seeds $\mathrm{Zn}(49.09 \mathrm{mg} / \mathrm{kg})$, Co $(3.86 \mathrm{mg} / \mathrm{kg})$ the $\mathrm{Zn}$ and Co concentrations are higher than the concentrations of $\mathrm{Zn}$ and $\mathrm{Co}$ in this study. These values are within the FAO/WHO permissible limit.

\section{Chlorinated organic compounds}

Generally, out of seventeen isomers of chlorinated organic compounds analyzed only five isomers were detected in all, two isomers of cyclodiens, one isomer each form dichloro diphenylethenes and hexachlorocyclohexane.

Table 2 presents mean levels of cyclodienes compounds in melon seed. In Nigeria, heptachlor was among the ban chemicals. Heptachlor concentration $(\mathrm{mg} / \mathrm{kg})$ is observed in Bida, Borgu and Saki. Saki had the highest concentration $(0.067 \mathrm{mg} / \mathrm{kg})$ followed by Bida $(0.037 \mathrm{mg} / \mathrm{kg})$ and the lowest

TABLE 2. Mean concentrations $(\mathrm{mg} / \mathrm{kg}$ ) of cyclodienes in Melon Seed

\begin{tabular}{|c|c|c|c|c|c|c|}
\hline OCPs & Bida & Borgu & Mokwa & Saki & Suleja & MRL \\
\hline Heptachlor & $0.037 \pm 0.00$ & $0.026 \pm 0.00$ & $<0.0094$ & $0.067 \pm 0.00$ & $<0.0094$ & 0.02 \\
\hline Hept-epoxide & $<0.023$ & $<0.023$ & $<0.023$ & $<0.023$ & $<0.023$ & 0.02 \\
\hline Aldrin & $<0.031$ & $<0.031$ & $<0.031$ & $<0.031$ & $<0.031$ & 0.05 \\
\hline Dieldrin & $<0.072$ & $<0.072$ & $<0.072$ & $<0.072$ & $<0.072$ & 0.02 \\
\hline Endrin & $<0.112$ & $<0.112$ & $<0.112$ & $<0.112$ & $<0.112$ & 0.01 \\
\hline Endrin $\mathrm{CHO}$ & $<0.057$ & $0.07 \pm 0.00$ & $<0.057$ & $<0.057$ & $<0.057$ & 0.01 \\
\hline Endosulfan I & $<0.060$ & $<0.060$ & $<0.060$ & $<0.060$ & $<0.060$ & 0.10 \\
\hline Endosulfan II & $<0.141$ & $<0.141$ & $<0.141$ & $<0.141$ & $0.062 \pm 0.00$ & 0.10 \\
\hline
\end{tabular}


Borgu at $0.026 \mathrm{mg} / \mathrm{kg}$. Heptachlor concentrations observed in this study were above the MRL value. The principal contact of human beings to heptachlor is via contaminated foods [33]. The farmers engaged in the use of heptachlor to kill ants, termites and other soil insects and on crops [34]. Endosulfan has two isomers $(\alpha, \beta)$ and their metabolite is endosulfan sulfate [35]; used to control ectoparasites on farm animals and pest [36]. The concentration (0.062) of endosulfan II was observed only in Suleja and below the maximum residual limit. Endrin aldehyde is observed only in Borgu $(0.07 \mathrm{mg} / \mathrm{kg})$ and above the maximum residual limit. All other isomers of cyclodienes were either zero or below their respective detection limits.

DDE is a fat soluble; endocrine disruptor [37]; weak antiandrogen [38]; neurotoxic, cause oxidative stress and damage brain's dopaminergic system; exposure link to Alzheimer's and Perkinson disease in human [39]. Table 3 shows the mean concentration $(\mathrm{mg} / \mathrm{kg})$ of the four isomers of dichloro diphenylethene in all five towns. The concentration of DDE was only observed in Bida. All other isomers and in all other towns were below their respective detection limit. However, the concentration of DDE observed in Bida is higher than the maximum residual limit. DDT is reductively dechlorinated to DDD and dehydrochlorinated to DDE [40], generally by the action of microorganism [41] and the metabolites are more stable and persistent than the parent compound [40]. The residue level of DDE is a reflection of applications.

Table 4 presents the mean level $(\mathrm{mg} / \mathrm{kg})$ of hexachlorocyclohexane in melon. Only $\lambda$-BHC was detected in three sites - Bida, Borgu and Saki. The highest $\lambda$-BHC $(\mathrm{mg} / \mathrm{Kg})$ is observed in Borgu (0.31) followed by Bida (0.26) and the lowest in Saki (0.07). These concentrations were higher than maximum residual limit of 0.05 as stipulated by EU.

Table 5 shows the overall mean concentrations $(\mathrm{mg} / \mathrm{kg})$ of the heavy metals studied in all the five locations. The overall mean concentrations of all the metals in a decreasing order for every locations are as follows: Bida $>$ Borgu $>$ Saki $>$ Suleja. Melon sample from Mokwa was free of organochlorine compounds.

TABLE 3. Mean levels ( $\mathrm{mg} / \mathrm{kg}$ ) of dichloro diphenylethene in melon seed

\begin{tabular}{lcccccc}
\hline OCPs & Bida & Borgu & Mokwa & Saki & Suleja & MRL \\
\hline p, p' -DDD & $<0.082$ & $<0.082$ & $<0.082$ & $<0.082$ & $<0.082$ & 0.05 \\
p,p' -DDE & $0.17 \pm 0.00$ & $<0.040$ & $<0.040$ & $<0.040$ & $<0.040$ & 0.05 \\
p,p' -DDT & $<0.078$ & $<0.078$ & $<0.078$ & $<0.078$ & $<0.078$ & 0.05 \\
Methoxychlor & $<0.405$ & $<0.405$ & $<0.405$ & $<0.405$ & $<0.405$ & 0.01 \\
\hline
\end{tabular}

TABLE 4. Mean level ( $\mathrm{mg} / \mathrm{kg}$ ) of hexachlorocyclohexane in melon seed

\begin{tabular}{lcccccc}
\hline OCPs & Bida & Borgu & Mokwa & Saki & Suleja & MRL \\
\hline$\alpha$-BHC & $<0.063$ & $<0.063$ & $<0.063$ & $<0.063$ & $<0.063$ & 0.05 \\
$\beta$-BHC & $<0.094$ & $<0.094$ & $<0.094$ & $<0.094$ & $<0.094$ & 0.05 \\
$\lambda$-BHC & $0.26 \pm 0.00$ & $0.31 \pm 0.01$ & $<0.057$ & $0.07 \pm 0.01$ & $0.01 \pm 0.00$ & 0.05 \\
$\delta$-BHC & $<0.017$ & $<0.017$ & $<0.017$ & $<0.017$ & $<0.017$ & 0.05 \\
\hline
\end{tabular}

TABLE 5. Total mean levels ( $\mathrm{mg} / \mathrm{kg}$ ) OCPs in melon seed of the selected locations

\begin{tabular}{lcccc}
\hline Bida & Borgu & Mokwa & Saki & Suleja \\
\hline $0.47 \pm 0.01$ & $0.40 \pm 0.01$ & ND & $0.14 \pm 0.01$ & $0.07 \pm 0.01$ \\
\hline
\end{tabular}

\section{CONCLUSION}

Organochlorine pesticides residues and five metals in melon seed collected from five towns in Nigeria were investigated. The study revealed the occurrence of pesticides residue examined. The overall metal content per site of the studied elements in the selected sites was determined and it was in the following decreasing order: Mokwa $>$ Bida $>$ Suleja $>$ Borgu $>$ Saki. The mean metal concentrations was in the following decreasing order: $\mathrm{Pb}>\mathrm{Zn}>\mathrm{Ni}>\mathrm{Co}>\mathrm{Cd}$. With exceptions of locations where $\mathrm{Ni}$ and $\mathrm{Pb}$ were below detection limit, the concentrations of $\mathrm{Pb}, \mathrm{Cd}$ and $\mathrm{Ni}$ in other locations were above WHO/FAO recommended limit. Concentrations of $\mathrm{Zn}$ and $\mathrm{Co}$ were below WHO/FAO limits.
Generally, out of seventeen isomers of chlorinated organic compounds analyzed only four isomers were detected in all, two isomers of cyclodiens, one isomer each form dichloro diphenylethenes and hexachlorocyclohexane. The overall OCPs content per site of the studied elements in the selected sites was determined and it was in the following decreasing order: Bida > Borgu $>$ Saki $>$ Suleja. OCPs were not detected in melon samples obtained from Mokwa. With exception of endosulphan II, endrin aldehyde, heptachlor, DDE and $\lambda-$ BHC were above their respective maximum residual limit.

To prevent or minimize long term human exposure and or inhalation to OCPs and heavy metals especially the farmers and consumers of melon. This could be done through environmental management, proper assessment and remediation of contaminated areas and maintain heavy metals as slow as possible. Future environmental monitoring is highly recommended. Continuous education and training should be provided to the farmers, emphasizing on the environmental implications of their use and exposure to pesticide residues. 


\section{ABBREVIATION}

BHC

ECD

Endrin $\mathrm{CHO}$

EU

Endosul

FFDCA

ND

OCPs

p,p'-DDD

p,p"-DDE

p,p"-DDT
Benzene hexachloride

Electron Capture Detector

Endrin Aldehyde

European Union

Endosulfan

Federal Food, Drug and Cosmetic Act

Not detected

Organochlorine Pesticides Residue

Para, para-dichlorodiphenyldichloroethane

Para, para-dichlorodiphenylchloroethylene

Para, para-dichlorodiphenyltrichloroethane

\section{REFERENCE}

1. Global Report on Food Crises, 2018, Food Security Information Network. https://ec.europa.eu/knowledge4policy/publication/globalreport-food-crises-2019_en.

2. Mohammed, B.T., 2011. Socio-economic analysis of melon production in Ifelodun Local Government Area, Kwara State, Nigeria. Journal of Development and Agricultural Economics, 3(8), pp.362-367.

3. Sadiq, M., Abubakar, M. and Yusuf, T., 2013. Economies of Scale and Cost Efficiency in Small Scale Egusi Melon Production in Bida Local Government Area of Niger State, Nigeria. Journal of Agriculture and Veterinary Science, 2(6), pp.92-97.

4. Agba, O.A., 2004. Effect of Nitrogen and Phosphorus On the Growth and Yield Of Egusi Melon (Colocynthis citrullus) in Cross River State. Journal of Agriculture, Forestry and the Social Sciences, 2(2), pp.17.

5. Agba, O.A., Adinya, I.B., Agbogo, E.A., Oniah, M.A., Tiku, N. and Abam Prince, L.M., 2009. Responses of egusi melon (Colocynthis citrollus L.) to poultry manure in Obubra, Cross River South-South Nigeria. Wilolud Online Journals. Continental Journal of Agronomy, 3, pp.13-18.

6. Olaniyi, J.O., 2008. Growth and seed yield response of egusi melon to nitrogen and phosphorus fertilizers application. American-Eurasian Journal of Sustainable Agriculture, 2(3), pp.255-260.

7. Albishri, H.M., Almaghrabi, O.A. and Moussa, T.A., 2013. Characterization and chemical composition of fatty acids content of watermelon and muskmelon cultivars in Saudi Arabia using gas chromatography/mass spectroscopy. Pharmacognosy Magazine, 9(33), pp.58-66.

8. Ivanova, P.H., 2012. The melons-raw material for food processing. In 50 years FoodRDI. Food Technologies and Health, International Scientific-Practical Conference, Plovdiv, Bulgaria, Proceedings, Food Research and Development Institute, pp. 23-26.

9. Jeffrey, C., 1990. an outline classification of the Cucurbitaceae. In: Biology and utilization of the Cucurbitaceae, pp.449-463.

10. Chen, L., Kang, Y.H. and Suh, J.K., 2014. Roasting processed oriental melon (Cucumis melo L. var. makuwa Makino) seed influenced the triglyceride profile and the inhibitory potential against key enzymes relevant for hyperglycemia. Food Research International, 56, pp.236242.

11. Gill, N.S., Garg, M., Bansal, R., Sood, S., Muthuraman, A., Bali, M. and Sharma, P.D., 2009. Evaluation of antioxidant and antiulcer potential of Cucumis sativum L. seed extract in rats. Asian Journal of Clinical Nutrition, 1, pp.131-138.

12. Azhari, S., Xu, Y.S., Jiang, Q.X. and Xia, W.S., 2014. Physicochemical properties and chemical composition of Seinat (Cucumis melo var. tibish) seed oil and its antioxidant activity. Grasas y Aceites, 65(1), pp.1-8.

13. Atafar, Z., Mesdaghinia, A., Nouri, J., Homaee, M., Yunesian, M., Ahmadimoghaddam, M. and Mahvi, A.H., 2010. Effect of fertilizer application on soil heavy metal concentration. Environmental Monitoring and Assessment, 160(1-4), pp.83-89.

14. Ling, W., Shen, Q., Gao, Y., Gu, X. and Yang, Z., 2008. Use of bentonite to control the release of copper from contaminated soils. Australian Journal of Soil Research, 45(8), pp.618-623.

15. Basta, N.T., Ryan, J.A. and Chaney, R.L., 2005. Trace element chemistry in residual-treated soil. Journal of Environmental Quality, 34(1), pp.49-63.

16. Jones, L.H.P., Jarvis, S.C., Green, D.J. and Hayes, M.H.B., 1981. The fate of heavy metals in the chemistry of soil processes. John Wileyt and Sons, New York.

17. Sumner, M.E., 2000. Beneficial use of effluents, wastes, and biosolids. Communications in Soil Science and Plant Analysis, 31(11-14), pp.1701-1715.

18. Chaney, R.L. and Oliver, D.P., 1996. Sources, potential adverse effects and remediation of agricultural soil contaminants. In Contaminants and the soil environment in the Australasia-Pacific region, Springer, Dordrechtpp, 323-359.

19. Kumar, M., Lakshmi, C.V. and Khanna, S., 2008. Biodegradation and bioremediation of endosulfan contaminated soil. Bioresource Technology, 99(8), pp.3116-3122.

20. Siddique, T., Okeke, B.C., Arshad, M. and Frankenberger, W.T., 2003. Biodegradation kinetics of endosulfan by Fusarium ventricosum and a Pandoraea species. Journal of Agricultural and Food Chemistry, 51(27), pp.8015-8019.

21. Cooper, K., 1991. Effects of pesticides on wildlife, In Handbook of Pesticides Toxicology, Vol. 1. General Principles, Academic Press Inc, New York.

22. Brown, L.M., Burmeister, L.F., Everett, G.D. and Blair, A., 1993. Pesticide exposures and multiple myeloma in Iowa men. Cancer Causes \& Control, 4(2), pp.153-156.

23. Zhang, L., Dong, L., Shi, S., Zhou, L., Zhang, T. and Huang, Y., 2009. Organochlorine pesticides contamination in surface soils from two pesticide factories in Southeast China. Chemosphere, 77(5), pp.628633.

24. Nawab, A., Aleem, A. and Malik, A., 2003. Determination of organochlorine pesticides in agricultural soil with special reference to $\gamma$-HCH degradation by Pseudomonas strains. Bioresource Technology, 88(1), pp.41-46.

25. Manahan, S.E., 2002. Toxicological chemistry and biochemistry. CRC Press.

26. Campbell, P.G., 2007. Cadmium-a priority pollutant. Environmental Chemistry, 3(6), pp.387-388.

27. Baldwin, D.R. and Marshall, W.J., 1999. Heavy metal poisoning and its laboratory investigation. Annals of Clinical Biochemistry, 36(3), pp.267-300.

28. Oluwabamiwo, F., Adegoke, G., Denloye, S., Akinoso, R. and Bruno, D., 2015. Proximate composition and fatty acid profile of Nigerian melon seeds. Life Science Archives, 1(1), pp.59-65.

29. Lanre-Iyanda, T.Y. and Adekunle, I.M., 2012. Assessment of heavy metals and their estimated daily intakes from two commonly consumed foods (Kulikuli and Robo) found in Nigeria. African journal of food, agriculture, nutrition and development, 12(3), pp.6156-6169.

30. Ogunkunle, A.T.J., Bello, O.S. and Ojofeitimi, O.S., 2014. Determination of heavy metal contamination of street-vended fruits and vegetables in Lagos state, Nigeria. International Food Research Journal, 21(6). pp.2115-2120.

31. Savsatli, Y., Ozcan, A., Catal, M.İ., Seyis, F., Akbulut, M. and Turumtay, E.A., 2016. Trace elements in bitter melon (Momordica charantia L.) and their distribution in different plant parts. ARPN Journal of Agricultural and Biological Science, 11(11), pp.437-443.

32. Verma, V.N., 2015. Chemical composition and quantitative elemental investigation of bitter melon. World Scientific News, 16, pp.84-94.

33. ATSDR, 2007. Toxicological profile for arsenic. Agency for Toxic Substances and Disease Registry, Division of Toxicology, Atlanta, GA.

34. Olufade, Y.A., Sosan, M.B. and Oyekunle, J.A.O., 2014. Levels of organochlorine insecticide residues in cowpea grains and dried yam chips from markets in Ile-Ife, Southwestern Nigeria: a preliminary survey. Ife Journal of Science, 16(2), pp.161-170.

35. Wan, M.T., Kuo, J.N. and Pasternak, J., 2005. Residues of endosulfan and other selected organochlorine pesticides in farm areas of the Lower Fraser Valley, British Columbia, Canada. Journal of Environmental Quality, 34(4), pp.1186-1193. 
36. Ntow, W.J., Tagoe, L.M., Drechsel, P., Kelderman, P., Nyarko, E. and Gijzen, H.J., 2009. Occupational exposure to pesticides: blood cholinesterase activity in a farming community in Ghana. Archives of environmental contamination and toxicology, 56(3), pp.623-630.

37. Afful, S., Anim, A.K. and Serfor-Armah, Y., 2010. Spectrum of organochlorine pesticide residues in fish samples from the Densu Basin. Research Journal of Environmental and Earth Sciences, 2(3), pp.133-138.

38. Essumang, D.K., Togoh, G.K. and Chokky, L., 2009. Pesticide residues in the water and fish (lagoon tilapia) samples from lagoons in Ghana. Bulletin of the Chemical Society of Ethiopia, 23(1), pp.19-27.
39. Paul, A., Lajide, L., Aiyesanmi, A.F. and Lacorte, S., 2012. Residues of dichlorodiphenyltrichloroethane (DDT) and its metabolites in cocoa beans from three cocoa ecological zones in Nigeria. European Journal of Applied Sciences, 4(2), pp.52-57.

40. Yao, F.X., Jiang, X., Yu, G.F., Wang, F. and Bian, Y.R., 2006 Evaluation of accelerated dechlorination of $\mathrm{p}, \mathrm{p}^{\prime}$-DDT in acidic paddy soil. Chemosphere, 64(4), pp.628-633.

41. ATSDR, 2002. Toxicological profile for DDT, DDE, and DDD. US Department of Health and Human Services, Public Health Service, Agency for Toxic Substances and Disease Registry. 